\title{
The Evaluation of Coramil Model Program in KODIM (District Military Command) 1207/BS at Pontianak City
}

\author{
Edy Kuswanto ${ }^{1)}$, M. Chiar $^{2}$, Sukmawati $^{3)}$ \\ ${ }^{1)}$ Universitas Tanjungpura, Pontianak, Indonesia \\ E-mail: armysinka97@yahoo.co.id \\ ${ }^{2)}$ Universitas Tanjungpura, Pontianak, Indonesia \\ E-mail: chiarfkip@gmail.com \\ ${ }^{3)}$ Universitas Tanjungpura, Pontianak, Indonesia \\ E-mail: sukmawati@fkip.untan.ac.id
}

\begin{abstract}
The Koramil Model program that is formed at this time, especially those in the Kodim 1207/BS Pontianak ranks has not yet described the expected results in accordance with the objectives of the establishment of the Koramil Model. This study aims to improve the quality of Apkowil through an evaluation of the Koramil Model program at Kodim 1207/BS Pontianak. This type of research is evaluative research. The program evaluation procedure for the Koramil Model in Kodim 1207/BS Pontianak in this study uses evaluation of the CIPP model (Context, Input, Process, and Product). The results of this study indicate that (1) the results of the context evaluation of the Koramil Model program at Kodim 1207/BS Pontianak containing program planning fall into less criteria; (2) the results of the evaluation of inputs (input) of the Koramil Model Program in Kodim 1207/BS Pontianak are included in the criteria of very few; (3) the results of the evaluation of the Koramil Model program implementation process at the Kodim 1207/BS Pontianak included in the criteria were not appropriate; (4) the results of the evaluation of the Koramil Model program at the Kodim 1207/BS Pontianak included in the criteria of lacking.
\end{abstract}

Keywords: Evaluation; Program; District Military Command

\section{INTRODUCTION}

Territorial Command Officers (Apkowil) are part of elements of the Army that carry out territorial development functions and tasks that are directly related to the social life of the community with the dynamics of the problems that the members must improve with an integrated and sustainable principle between one element and another related to achieving the desired goal. Therefore, in order to achieve these quality improvements, evaluation must be done to find out the problems faced and found solutions to solve these problems.

Professionalism and discipline which are two important things related must be owned by Apkowil in carrying out its duties. The process of achieving the target always experiences various obstacles and obstacles. To overcome this, various solutions are needed to begin the process of providing Apkowil personnel, education, training and supporting facilities in the territorial development process to face the challenges of task and modern war. Coaching and enhancing Apkowil's professionalism must be carried out continuously through a standardized system and pattern according to the needs and demands of the task that develops in the present (reform era) by avoiding ways that are oriented to individual tastes (leaders).

The existing Apkowil is formed from a variety of different backgrounds both regarding education, scientific discipline, health conditions, ethnicity, culture and assignments, and technological capabilities. With a diverse background, Apkowil must be able to keep up with the developments and dynamics that occur in the community, so that what must be done and done can be synergic with the target area. From the background or ability possessed by Apkowil today, it can be an obstacle or obstacle in carrying out tasks in the field. One of the most basic obstacles is Apkowil's educational background if 
faced with a background in public education. To that end, in responding to the real conditions faced by Apkowil, elements of the leadership of the Indonesian Army have compiled a Koramil Model program with the aim of being able to answer the development of social conditions in the community which aims as guidance and improvement of Apkowil capabilities in each Military District Command.

The Koramil Model is a Koramil that is close to ideal and represents most of the characteristics of the Kodim region and is used as a model for other Koramil and as a means used to prepare and improve the ability of new members serving in Satkowil before the member is assigned to the community, one of the Koramil Models is the Koramil Model at Kodim 1207/BS Pontianak (Army Territorial General Staff, 2014: 2).

Based on the initial observations of researchers conducted on February 26 to 272018 at the Koramil Model in Kodim 1207/BS Pontianak, it was shown that the Koramil Model program was formed at this time, especially those in the Kodim 1207/BS Pontianak rank describes the expected results in accordance with the objectives of the establishment of the Koramil Model, this is because there are several factors, including: (1) inappropriate selection of bases, (2) inadequate selection of quality and quantity of personnel, (3) development of expected personnel capabilities still not maximal, (4) management of data space that is not sufficient, so that there are still several workspaces that are still joined in one other room, and (5) the number of references in the library is still small.

The Koramil Model program is implemented throughout the year, meaning that in each year the program is still programmed. But in its implementation, the Koramil who was appointed as the Koramil Model was only limited to implementing the program. The program carried out only produces administrative products which include planning activities and reporting on the implementation of activities and accountability for budget support. While to find out the level of success or failure of the program has never been carried out specifically evaluation. Evaluation is often ignored so that until now there is no known level of success and constraints of the implementation of the Koramil Model program.

Based on the problems that the researchers found, the researchers argued that these problems must be resolved immediately and immediately withdrawn solutions to overcome them. It is because if these problems continue to be left and the solution is not immediately sought, it will become an obstacle or a barrier, especially for the program and the existence of the Koramil Model.

One solution that is considered appropriate in this problem is by evaluating the Koramil Model program at Kodim 1207/BS Pontianak. Evaluation program in the Koramil Model is necessary with the aim of obtaining authentic data about the situation or situation that can later be taken into consideration in determining the next policy and obtaining some information that can describe the actual conditions of the Koramil Model. It is because the results of this program evaluation are important to develop the same program elsewhere and make decisions about the sustainability of a program, whether the program needs to be continued, repaired or stopped (Chitteden in Zainal Arifin, 2016: 15).

Finally, based on the explanation above, researchers are interested in researching the Koramil Model program which aims to provide solutions to the problems of the Koramil Model program at Kodim 1207/BS Pontianak with the title "Evaluation of the Model Koramil Model at Kodim 1207/BS Pontianak".

\section{RESEARCH METHOD}

This type of research is evaluative research. The approach method used in this study is an evaluative approach. In this study carried out to obtain data and produce conclusions in the field in connection with the evaluation of the Koramil Model program at Kodim 1207/BS Pontianak.

\section{Evaluation Procedure}

The program evaluation procedure for the Koramil Model in Kodim 1207/BS Pontianak in this study uses evaluation of the CIPP model (Context, Input, Process, and Product) as follows:

a. Context evaluation to serve planning decision. This evaluation context helps plan decisions, determines the needs be achieved by the program and formulates the objectives of the Koramil Model program in Kodim 1207/BS Pontianak.

b. Input evaluation, structuring decision. This evaluation helps to regulate decisions, determine available sources, what alternatives are taken, what plans and strategies to achieve the needs of the Koramil Model in the Pontianak 1207/BS Kodim and work procedures to achieve them.

c. Process evaluation, to serve to implement the decision. Process evaluation to help implement decisions.

d. Product evaluation, to serve recycling decision. Product evaluation to help further decisions about the Koramil Model program at Kodim 1207/BS Pontianak.

The CIPP evaluation procedure for the Koramil Model program in Pontianak's Kodim $1207 / \mathrm{BS}$ is a comprehensive framework to direct the implementation of formative evaluation and summary evaluation of program objects, projects, personnel, products, institutions, and systems.

Data Source 
The source of this research data is qualitative data sources. The primary data source, namely the data obtained by plunging directly into the field which will be the object of research to obtain the data needed in this study, are respondents who respond or answer the researchers' questions, both in the form of oral and written questions given to Danramil and Babinsa Koramil 1207-02/PS. Whereas secondary data sources in this study are in the form of documents or records related to the research that the researcher is doing.

Research Sites

This research was conducted at Koramil 1207-02/PS Kodim 1207/BS Jalan Purnama II Pontianak, West Kalimantan.

\section{Data Collection Techniques and Tools}

1. Data Collection Techniques

In this study researchers used three data collection techniques, namely:

a. Non-Participant Observation

b. Direct Communication Techniques

c. Documentation

2. Data Collection Tool

The data collection tools used by researchers in this study are:

a. Interview Guide

b. Field Notes

c. Questionnaire (Koesioner)

d. Documentation Tools

Data Analysis Technique

In this study, the researcher used Miles and Huberman model data analysis techniques which are carried out interactively and continue continuously until complete, so the data is saturated.

Data analysis activities that must be carried out by researchers are:
a. Data Collection
b. Data reduction
c. Presentation (Display) Data
d. Verification (Withdrawal) Conclusion

Data Validity Check Technique

In this study, the researcher used the data validity techniques as follows:

a. Extend the observation period

b. Continuous observation

c. Triangulation

d. Member check

\section{RESULT AND DISCUSSION}

\section{A. Result}

The research data will be discussed descriptively about the research that has been done at the Koramil Model in Kodim 1207/BS Pontianak. The research carried out in Koramil Model Kodim 1207/BS Pontianak involved various parties as research respondents, where the respondents involved the Danramil and Babinsa Koramil 1207-02/PS
Kodim 1207/BS Pontianak. Research activities can proceed according to the mechanism and procedures of the CIPP evaluation model so that the following results can be obtained:

1. The context of the Koramil Model Program at Kodim 1207/BS Pontianak

Context evaluation aspects in the program include: (1) Planning of Personnel Component Programs, (2) Planning of Material Component Programs, (3) Planning of Training Component Programs, (4) Planning of Base Component Programs, (5) Planning of Software Component Programs, (6) Komsos Program Planning, (7) Planning for TNI Service Programs, and (8) Planning for Wanwil Programs.

The Koramil Model Personnel component program planning in Kodim 1207/BS Pontianak is not yet appropriate, this is because the Koramil Model in Kodim 1207/BS Pontianak still do not know in detail about the criteria and conditions for personnel who will be recruited as Koramil Model personnel, so the Koramil Model is Kodim 1207/BS Pontianak still has not been able to make plans according to the personnel needed. Therefore, to overcome this, the Koramil Model in Kodim 1207/BS Pontianak is always looking for clear information about the details of the criteria and terms of personnel who will be recruited as Koramil Models.

The planning of the material component program is also not appropriate, this is because the material submission made by the Koramil Model at Kodim 1207/BS Pontianak is hampered by the limited space that will be used to place the material, so the Koramil Model in Pontianak Military Command 1207/BS still cannot plan according to the material we need.

Planning a training component program created by the Koramil Model at Kodim 1207/BS Pontian and in accordance with the Koramil Model training program from every exercise activity to the final stage of training activities.

Planning the base component program is not yet appropriate, this is because the facilities and infrastructure contained in the Koramil Model in Kodim 1207/BS Pontianak are still lacking.

The software component program planning is not appropriate, this is because when the Koramil Model Kodim 1207/BS Pontianak wanted to make a proposal for the procurement of software, the Koramil Model Kodim 1207/BS Pontianak was still limited to the room to be used to place the software, so the Kodim Model Military Command 1207/BS Pontianak still cannot plan according to the software needed.

The Program that Komsos has been planned is appropriate, Koramil Model Kodim 1207/BS Pontianak has made a plan to implement the Komsos in accordance with the Koramil program. The model 
of each activity that will be conducted by the Koramil Model Kodim 1207/BS Pontianak is carried out during the implementation of Komsos.

Planning for the TNI Service program is appropriate, Koramil Model Kodim 1207/BS Pontianak has made plans for the implementation of the TNI Service which is in accordance with the Koramil program Model of every activity that will be carried out in the implementation of the TNI Service.

Planning for the Wanwil program is appropriate, Koramil Model Kodim 1207/BS Pontianak has made Wanwil implementation plans that are in accordance with the Koramil program. The model of each activity will be implemented during the implementation of the Wanwil.

Based on the data from the Interview Major Inf Teguh Rahman as the Commander in the Koramil Model Kodim 1207/BS Pontianak, it can be concluded that the completeness of the context aspects of the Koramil Model at Kodim 1207/BS Pontianak only reaches a value of 50 . If the data is interviewed about context evaluation at the Koramil Model in the Kodim 1207/BS Pontianak, it only reached 50 results and the evaluation of the context was included in poor criteria.

This value is obtained from eight (8) plans that must be made to be a requirement as a Koramil Model, found only four (4) plans that have been made, namely (1) Planning of the Component Training Program, (2) Komsos Program Planning, (3) Planning of the Community Service Program TNI, and (4) Wanwil Program Planning. As for the other four (4) plans not yet available, consisting of (1) Planning of Personnel Component Program, (2) Planning of Material Component Program, (3) Planning of Base Component Program, and (4) Planning of Software Component Programs.

Observation data shows that the context of the Koramil Model in Kodim 1207/BS Pontianak is included in the criteria of less. From eight (8) plans that must be made for the requirements to become Koramil Model only four components of the Koramil Model program in the existing Kodim 1207/BS Pontianak, namely (1) Planning of the Training Component Program, (2) Komsos Program Planning, (3) Planning of the TNI Service Program, and (4) Planning of the Wanwil Program. While the remaining four plans do not yet exist, consisting of (1) Planning of Personnel Component Program, (2) Planning of Material Component Programs, (3) Planning of Base Component Programs and (4) Planning of Software Component Programs.

In addition to conducting interviews and observations, researchers also distributed questionnaires to Babinsa Koramil1207-02/PS as Koramil Model at Kodim 1207/BS Pontianak. For more details, the results of the average evaluation questionnaire The context of the Koramil Model program in the Pontianak Kodim 1207/BS is illustrated in the figure below:

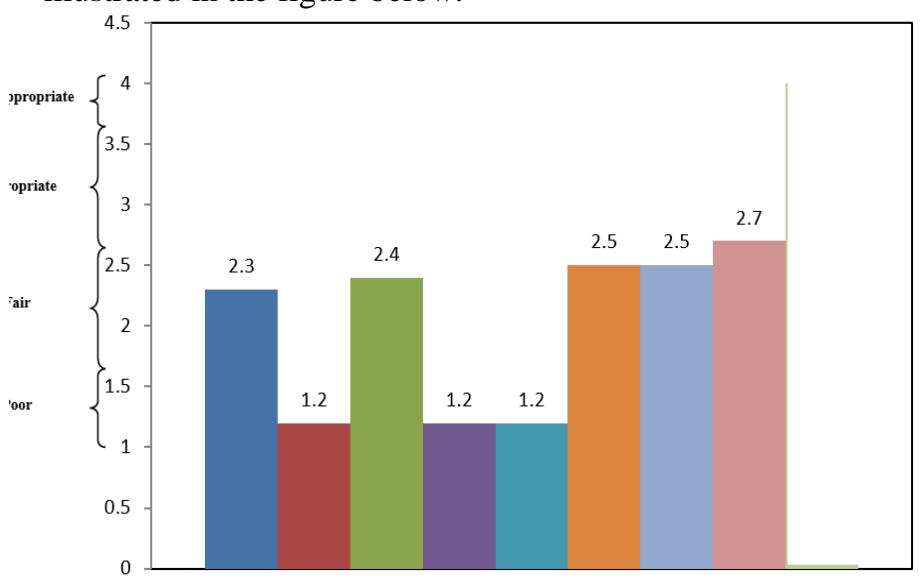

Fig. 1 Results of The Average Evaluation Questionnaire Context of The Koramil Model

Program at Kodim 1207/BS Pontianak Information :

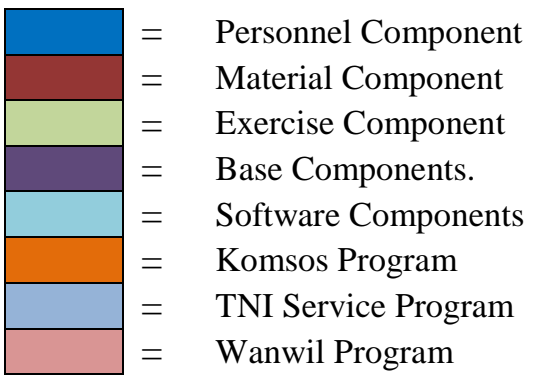

Based on Figure 1, the data obtained is that the average Personnel Component Program is 2.3 (Fair), the Material Component Program is 1.2 (Poor), the Training Component Program is 2.4 (Fair), the Base Component Program is 1.2 (Poor), Software Component Program is 1.2 (Poor), Komsos Program is 2.5 (Fair), Bakti TNI Program is 2.5 (Fair), and Wanwil Program is 2, 7 (Appropriate).

The results of the recapitulation of the average evaluation of the context of the Personnel Component Program, the Material Component Program, the Training Component Program, the Base Component Program, the Software Component Program, the Komsos Program, the TNI Service Program and the Wanwil Program are 2.0 in the appropriate criteria. Based on the results of the average recapitulation of the context evaluation questionnaire for each program that has been presented by the researcher, it can be concluded that the evaluation of the context of the Koramil Model at the Pontianak 1207/BS Kodim meets the criteria accordingly.

2. Enter the Koramil Model Program at Kodim 1207/BS Pontianak

Input evaluation aspects include: (1) Inputting the Personnel Component Program, (2) Inputting the Material Component Program, (3) 
Entering the Training Component Program, (4) Input of the Base Component Program, (5) Inputting the Software Component Program, (6) Enter the Komsos Program, (7) Enter the TNI Service Program, and (8) Enter the Wanwil Program.

The input of the Koramil Model personnel component program in Kodim 1207/BS Pontianak was not yet appropriate, this was because the Koramil Model in Kodim 1207/BS Pontianak still did not know in detail about the criteria and conditions for personnel who would be recruited as Koramil Model personnel, either from rank, position, duties, level of education, physical and spiritual health. So that the Koramil Model at the Kodim 1207/BS Pontianak still could not make plans according to the personnel needed.

The input of the Material Component Program is also not yet appropriate, this is because material submissions in the form of weapons, ammunition, Ranmor, Randis, Alkom, Aloptic, Alkapsat and Alkapsus, Koramil Model Kodim 1207/BS Pontianak are still limited to the space that will be used to place the material, so Model Koramil has not been able to do planning in accordance with the material needed.

Enter the program component of the training made by the Koramil Model in Kodim 1207/BS Pontianak has been appropriate, this is evidenced by the training program plan that has been made by the Koramil Model Kodim 1207/BS Pontianak, both individual training up to the training of the Koramil Model and Koramil Model Kodim 1207/BS Pontianak has also made plans in accordance with the Koramil Model training program from each exercise activity to the termination stage.

Input, the base component program, is not appropriate, this is due to the position of the Koramil Model in the middle of the city, so it is very difficult to build office facilities, housing, and supporting facilities in accordance with the Koramil Model base component program due to the narrow land area of the Koramil Model in Kodim 1207/BS Pontianak .

Entering the software component program is not appropriate, this is because the software usage, we are still limited to the space that will be used to place the software, so the Pontianak Kodim 1207/BS Koramil Model still cannot plan according to the software we need.

The input of the Komsos program is appropriate, Koramil Model Kodim 1207/BS Pontianak has made a plan for the implementation of Komsos which is in accordance with the Koramil Model program which includes, selecting targets / objects, determining the forms of Komsos, determining the time and place according to the scope of duties and responsibilities of each activities that will be carried out during the implementation of the Social Security Committee.
The Bakti TNI program was in accordance, Koramil Model Kodim 1207/BS Pontianak had made plans for the implementation of the TNI Service which was in accordance with the Koramil Model program which included targeting (physical and nonphysical) in accordance with the area of responsibility of each activity to be carried out in the implementation of the TNI Service.

Entering the Wanwil program has not been appropriate, because the task area of each personnel is too broad so the Kodim Model Koramil has difficulty in planning Wanwil activities according to the scope of duties and responsibilities to be carried out.

Based on the data from Major Inter Interview Teguh Rahman as Commander in Koramil Model Kodim 1207/BS Pontianak, it can be concluded that the completeness of the Koramil Model input aspect in Kodim 1207/BS Pontianak only reached 37.5 . If the data from the interview about input evaluation in the Koramil Model in Kodim 1207/BS Pontianak only reaches 37.5, then the input evaluation is in very poor criteria.

This value is obtained from eight (8) inputs that must be made for the requirements to become a Koramil Model, only three (3) input the Koramil Model program in the existing Pontianak Kodim 1207/BS, namely (1) Enter the Training Component Program, (2) Enter the Program Komsos, and (3) Enter the TNI Service Program. While five (5) other inputs that do not yet exist are (1) Input Personnel Component Program, (2) Input Material Component Program, (3) Input of Base Component Program, (4) Input Software Component Programs, and (5) Program Input Wanmil.

Observation data shows that input to the Koramil Model at the Kodim 1207/BS Pontianak is included in the criteria of very poor. Of the eight (8) inputs that must be made for the requirements to become a Koramil Model, only three enter the Koramil Model program in the existing Pontianak Kodim 1207/BS, namely (1) Training Component Program, (2) Enter the Komsos Program, and (3) Input TNI Service Program. While the remaining five entries that do not yet exist are Input (1) Personnel Component Program, (2) Input of Material Component Program, (3) Input of Base Component Program, (4) Input of Software Component Program, and (5) Input of Program.

In addition to conducting interviews and observations, researchers also distributed questionnaires to Babinsa Koramil 1207-02/PS as Koramil Model at Kodim 1207/BS Pontianak. The results of the average questionnaire evaluation input for the Koramil Model program at the Pontianak Kodim 1207/BS are illustrated in the following figure: 


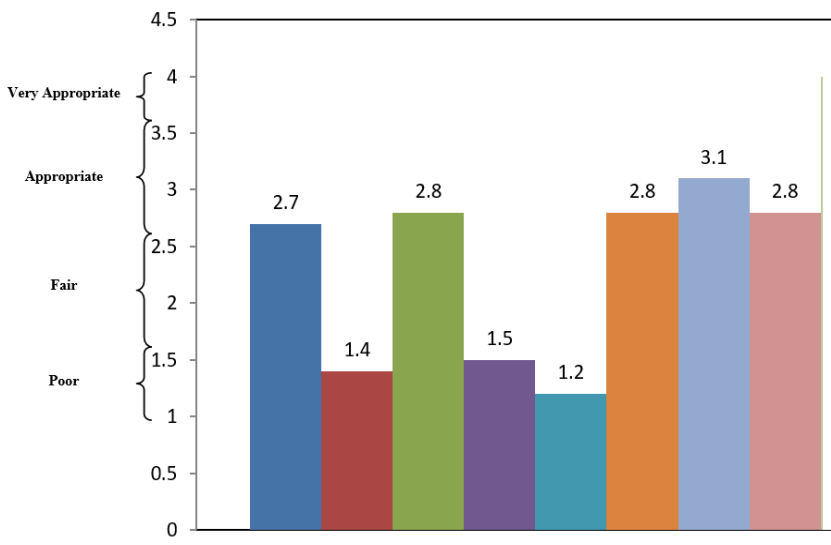

Fig. 2 Results of The Average Evaluation

Questionnaire Input into The Koramil Model Information:

program at Kodim 1207/BS Pontianak.

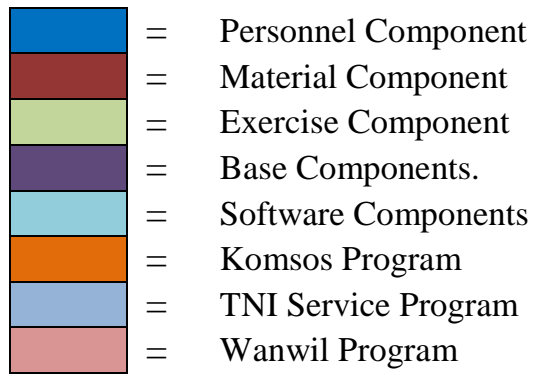

Based on Figure 2, data is obtained that the average Component of Personnel Recruitment is 2.7 (Appropriate), the Material Component as needed is 1.4 (Fair), the Exercise Activity component is 2.8 (Appropriate), the Component is the Base is 1.5 (Poor), Software Components as needed are 1.2 (Poor), Komsos Program Activity is 2.8 (Appropriate), Bakti TNI Program Activities are 3.1 (Appropriate), and Wanwil Program Activities is 2.8 (Appropriate).

Average recapitulation results of input evaluation Components of Personnel Recruitment, Material Components as needed, Components of Exercise activities, Components of Base Base, Software Components according to needs, Community Program Activities, TNI Service Program Activities, and Wanwil Program Activities are 2.28 and included insufficient criteria corresponding.

Based on the results of the recapitulation of the average evaluation of each component of the program that has been presented by the researcher, it can be concluded that the evaluation of the Koramil Model input in the Kodim 1207/BS Pontianak in the criteria is quite appropriate.

3. The process of Implementing the Model Koramil Program at Kodim 1207/BS Pontianak

Process evaluation aspects in the implementation of the Koramil Model program in Kodim 1207/BS Pontianak consisting of: (1)
Personnel Component Program Process, (2) Process of Material Component Program, (3) Process Component Training Program, (4) Base Component Program Process, ( 5) Software Component Program Program Process, (6) Komsos Program Process, (7) TNI Service Program Process and (8) Wanwil Program Process.

The Koramil Model personnel component program in Kodim 1207/BS Pontianak is not yet appropriate; this is because the recruitment of personnel has not been maximized, so the Koramil Model in the Kodim 1207/BS Pontianak still has many shortcomings and personnel have not been compiled according to rank, position. Tasks, functions, level of education, physical health, and spiritual health.

The process of the Material Koramil Model component program in Kodim 1207/BS Pontianak is also not yet appropriate; this is because the material of the Koramil Model in the Kodim 1207/BS Pontianak still has minimal, both weapons, ammunition, Ranmor, Randis, Alkom, Aloptik, Alkapsat, and Alkapsus.

The program process of the components of the training made by the Koramil Model in Kodim 1207 / Pontianak Pontianak was not appropriate, in the implementation of the training program, both individual training and the training of the Koramil Model Unit, Koramil Model in Kodim 1207/BS Pontianak still lacked the facilities used for the implementation of the training program from each implementation of training activities up to the termination stage.

The base component program process is not yet appropriate so that many rooms that should have their own space are forced to be combined due to lack of facilities that the Pontianak Military Command Kodim 1207/BS Model has, both office facilities, housing, and other supporting facilities.

The software component program process is not appropriate; this is because in the procurement of software, Koramil Model Kodim 1207/BS Pontianak still lacks in software that matches the Koramil Model and what is needed.

The Komsos program process, Koramil Kodim 1207/BS Pontian Model has coordinated, supervised, recorded facts/data and the actual development of the implementation of Komsos activities in the Koramil area with the relevant agencies in accordance with the strategy to obtain and find out the community's response to the Komsos activities.

The Bakti TNI Koramil program process Model Kodim 1207/BS Pontianak has coordinated, recorded facts/data and actual developments as well as compiled reports on TNI Service activities with relevant authorities in accordance with the timeline to obtain and find out the community's response to the TNI Service activities. 
The Wanwil Koramil program process The Kodim 1207/BS Pontianak model has carried out and maintained communication between the Koramil and Babinsa, the Danramil with the Kecamatan in the framework of Wanwil activities to obtain directions and instructions needed in the framework of Wanwil activities.

Based on the data from Interview Major Inf Teguh Rahman as Commander in Koramil Model Kodim 1207/BS Pontianak, it can be concluded that the evaluation process of the Koramil Model program in Kodim 1207/BS Pontianak only achieved 37.5 with very poor criteria. If the data from the interview about the process evaluation at Koramil Model Kodim 1207/BS Pontianak only reaches a value of 37.5 then the evaluation of the process is included in the very poor criteria.

This value is obtained from eight (8) results of the process that must be made for the requirements to become Koramil. The model is only three (3) results of the Koramil Model program process in the existing Kodim 1207/BS Pontianak, namely (1) the results of the Komsos Program Process, (2) results in The TNI Service Program Program and (3) the results of the Wanwil Program Process. Whereas the other five (5) were not yet included: Input (1) Personnel Component Program Process, (2) Material Component Program Process, (3) Training Component Program Process, (4) Base Component Program Process, and (5) Software Component Program Program Process.

Observation data shows that the process at the Koramil Model in the Kodim 1207/BS Pontianak is included in the criteria of very less. Of the eight (8) input that must be made for the requirements to become a Koramil Model, only three input the Koramil Model program in the existing Kodim 1207/BS Pontianak, namely (1) the Komsos Program Process, (2) TNI Service Program Process and (3) Process Wanwil Program. While the remaining five entries that do not yet exist are Input (1) Personnel Component Program Process, (2) Material Component Program Process, (3) Training Component Program Process, (4) Base Component Program Process, and (5) Software Component Program Process.

In addition to conducting interviews and observations, researchers also distributed questionnaires to the Babinsa Koramil Model at Kodim 1207/BS Pontianak. The results of the average questionnaire evaluation process for the Koramil Model program in the Pontianak 1207/BS Kodim are illustrated in the following figure:

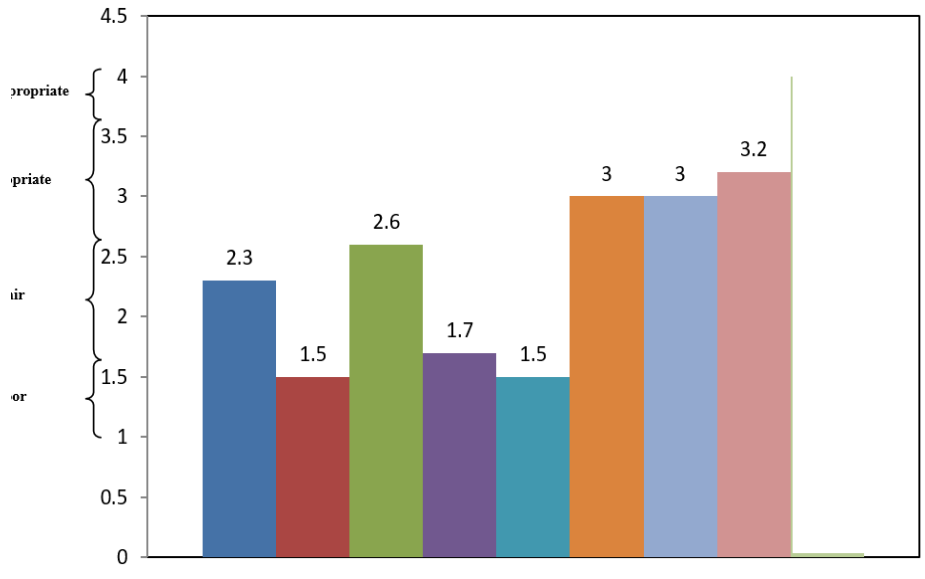

Fig. 3 Results of The Average Questionnaire Evaluation Process for The Koramil Model Program at Kodim 1207/BS Pontianak.

Information

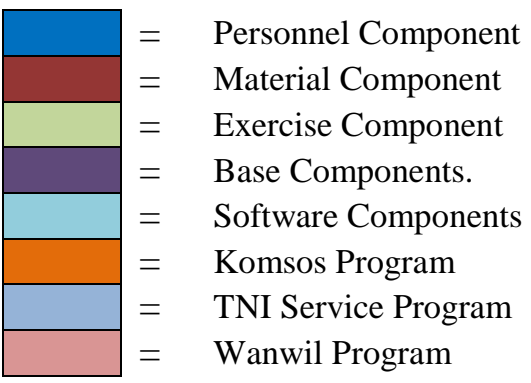

Based on Figure 3, the data obtained is that the average for evaluation The process of recording Personnel Components is 2.3 (Fair), the process of meeting the needs of Material Components is 1.5 (Poor), the process of Exercise Component activity is 2.66 (Fair), the Base Component Strategic Process is 1.7 (Poor), the process of fulfilling the Software Component is 1.5 (Poor), the Komsos Program Process is 3.0 (Appropriate), the TNI Service Program Process is 3.0 (Appropriate), and the Wanwil Program Process is 2.8 (Appropriate).

The results of the average process evaluation recapitulation include the process of recording personnel components, the process of meeting the needs of material components, the activity process of training components, the process of baseline component strategy, the process of fulfilling software components, the Komsos program process, the TNI service program process, the Wanwil program process 2, 35 and included in the criteria is quite appropriate. Based on the results of the average recapitulation of each program component that has been presented by the researcher, it can be concluded that the evaluation of the Koramil Model program process in Kodim 1207/BS Pontianak is included in the criteria accordingly.

4. Results of the Koramil Model Program at Kodim 1207/BS Pontianak 
Evaluation aspects of the results of the implementation of the Koramil Model program at Kodim 1207/BS Pontianak consisted of: (1) Results of the Personnel Component Program, (2) Results of the Material Component Program, (3) Results of the Component Training Program, (4) Results of the Base Component Program, (5 ) Results of the Software Component Program, (6) Komsos Program Results, (7) Results of TNI Service Programs, and (8) Results of the Wanwil Program.

The results of the Koramil Model personnel component program at the Kodim 1207/BS Pontianak have not reached $100 \%$ and are not yet in line with TOP / DSPP because the strength of personnel in the Koramil only reached $65 \%$.

The results of the Material Koramil Model component program at Kodim 1207/BS Pontianak also have not been in the category of good and maternity conditions not reaching $100 \%$ and not yet in accordance with the TOP / DSPP and conditions not yet ready for use.

The program results of the training component made by the Koramil Model at Kodim 1207/BS Pontianak the ability of personnel to increase after getting an exercise program in accordance with the programs that have been implemented. The dexterity of personnel evidences it in carrying out tasks in the field.

The results of the program evaluation of the base components showed that the facilities, buildings (bases) needed in the Koramil model program were in poor condition, this was evidenced by the number of damaged facilities and the need for immediate renovation.

The results of the software component program have been met, can be used by personnel and in good condition, which consists of manuals for implementing the Koramil Model.

The results of the program of Komsos, Koramil Model Kodim 1207/BS The availability of changes in attitudes and behavior both individually and in groups from Komsos messages that have been conveyed by mastering the existing environmental conditions in the community to facilitate Komsos activities.

The results of the Bakti TNI Koramil program in the Kodim 1207/BS Pontianak Model show that the results of the implementation of the TNI Service activities with the relevant apparatus have not been in accordance with the statutes and the facts/data and actual developments found in the TNI Service activities have not been in accordance with the provisions.

The results of the Wanwil Koramil program The Kodim 1207/BS Pontianak model has not reported the implementation of Wanwil activities aimed at maintaining, and reporting changes/developments in the Koramil territorial data and maintaining communication between the Koramil and Babinsa, the Danramil with the District and Kodim.

Based on the data from the Interview Major Inf Teguh Rahman as Commander in the Koramil Model Kodim 1207/BS Pontianak, it can be concluded that the evaluation aspects of the Koramil Model Program in Kodim 1207 / Pontianak Pontianak only reached a value of 50 . If the interview data about the evaluation results in The Koramil Model at Kodim 1207/BS Pontianak only reached a value of 50 , included in poor criteria.

This value can be obtained from eight (8) results that must be made for the requirements to become Koramil New model four (4) results of the Koramil Model program in the existing Kodim 1207/BS Pontianak, namely (1) Results of the Exercise Component Program, (2) Program Results Software Components, (3) Komsos Program Results, and (4) TNI Service Program Results. Whereas for the other four (4) non-existent results including (1) Results of the Personnel Component Program, (2) Results of the Material Component Program, (3) Results of the Base Component Program, and (4) Results of the Wanwil Program.

Observation data shows that the results at the Koramil Model at the Kodim 1207/BS Pontianak are included in the criteria of very few. Of the eight (8) inputs that must be made for the requirements to become a Koramil Model only four of them entered the Koramil Model program in the existing Kodim 1207/BS Pontianak, namely (1) Results of the Training Component Program, (2) Program Software Component Results, (3 ) Komsos Program Results, and (5) Results of the TNI Service Program. While the remaining four entries that do not yet exist are Input (1) Results of the Personnel Component Program, (2) Results of the Material Component Program, (3) Results of the Base Component Program, and (4) Results of the Wanwil Program.

In addition to conducting interviews and observations, researchers also distributed questionnaires to the Babinsa Koramil Model at Kodim 1207/BS Pontianak. The results of the average evaluation questionnaire on the results of the Koramil Model program at the Kodim 1207 / Pontianak BS are illustrated in the following. 


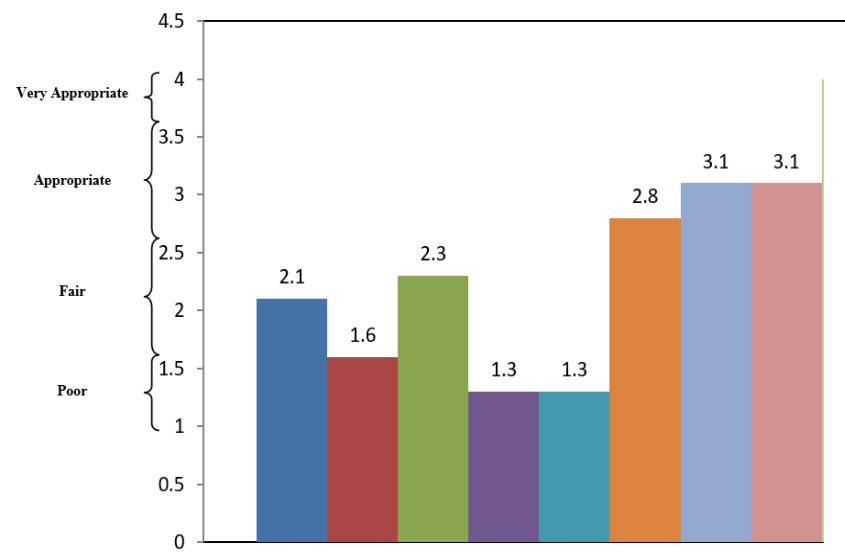

Fig. 4 Results of an Average Evaluation Questionnaire on The Results of The Koramil Model Information :

Program at Kodim 1207/BS Pontianak.

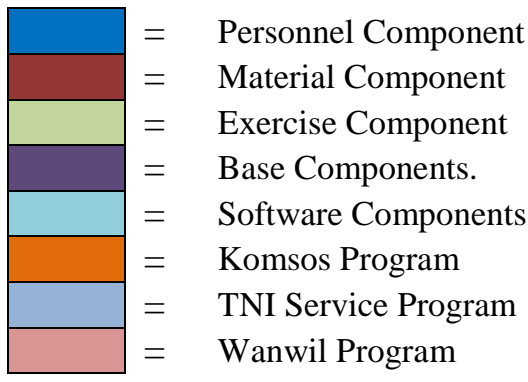

Based on Figure 4 obtained data that the average result of recruitment of personnel components is 2.1 (quite appropriate), the results of the fulfillment of the material component is 1.66 (quite appropriate), the results of the implementation of the training component are 2.3 (quite appropriate), The results of the Base Component strategic selection are 1.3 (Inadequate), the results of meeting the requirements of the Software Component are 1.3 (Less In Accordance), the results of the Komsos Program implementation are 2.8 (In Accordance), the Results of the TNI Service Program Implementation are 3, 1 (In Accordance), and the Implementation Results of the Wanwil Program are 3.1 (Appropriate).

The results of the recapitulation of the average evaluation of the results of the Koramil Model Program in Kodim 1207 / Pontianak Pontianak which included the Results of Personnel Component Program, Material Component Program Results, Training Component Components Program Results, Base Component Program Results, Software Component Results, Komsos Program Results, Program Results The TNI Service, and the Wanwil Program Results are 2.2 and are included in the criteria accordingly.

Judging from the results of the recapitulation of the results of the average evaluation of each program component that has been presented by the researcher, it can be concluded that the evaluation of the results of the Koramil Model in Kodim 1207/BS Pontianak in the criteria is quite appropriate.

\section{B. Discussion}

In this section is a discussion of the results of the research described in the previous section. The discussion of the results of this study is an attempt to explain the results of the analysis and answer the formulation of the proposed problem, namely how to evaluate the context, input, process, and product of the Koramil Model Program in Kodim 1207/BS Pontianak.

1. The context of the Koramil Model Program at Kodim 1207/BS Pontianak

Context evaluation conducted in this study included, (1) Planning of Personnel Component Program, (2) Planning of Material Component Program, (3) Planning of Component Training Programs, (4) Planning of Base Component Programs, (5) Planning of Software Component Programs, (6) Komsos Program Planning, (7) Planning for TNI Service Programs, and (8) Planning for Wanwil Programs.

Based on the results of interviews with Major Inf Teguh Rahman as Commander of the Koramil Model in Kodim 1207/BS Pontianak and observation, the context of the Koramil Model program in Kodim 1207/BS Pontianak which contained program planning only achieved 50 results with fewer criteria. Of the eight (8) planning that must be made for the requirements to become Koramil Model found only four (4) components of the Koramil Model program in the existing Pontianak Kodim 1207/BS, namely (1) Planning the Component Training Program, (2) Komsos Program Planning, (3) Planning for TNI Service Programs, and (4) Planning for Wanwil Programs. While for four (4) other plans that do not yet exist, consists of (1) Planning of Personnel Component Program, (2) Planning of Material Component Program, (3) Planning of Base Component Programs, and (4) Planning of Software Component Programs.

Based on the data from the recapitulation results, the average questionnaire distributed to Babainsa personnel which only reached 2.0 and included in the criteria was quite appropriate, with the details of the personnel component program was 2.3 (Fairly Appropriate), the Material component program was 1.2 (Less In accordance), the training component program is 2.4 (Fairly Appropriate), the base component program is 1.2 (Inadequate), the software component program is 1.2 (Less Compliant), the Komsos program is 2.5 (Fairly Appropriate) the TNI service program is 2.5 (Fairly Appropriate), and the Wanwil program is 2.7 (Appropriate).

The results of the interview data and questionnaire were strengthened by the results of an interview with Mayor Inf Baisumi as Officer of the 
Operations Section on 11 August 2018 stating that the planning at the Koramil Model at Kodim 1207/BS Pontian was all complete and complete, although there were some that were not in line with the planning requirements of the Koramil Model.

The context of the Koramil Model Program in Kodim 1207/BS Pontianak contains program planning that is very important and must be in each program. It is because planning has a function so that the goals become clear and directed, identify various obstacles and opportunities that exist in the environment and help to reduce risks and uncertainties so that uncertainty can be minimized.

The importance of planning in carrying out activities according to Arief Bowo's opinion (in Agus Wiranto 2014: 2) which reveals that planning is very important and must exist in each program because planning has several functions as follows:

a. Purpose becomes clear and directed. Planning as a first step towards achieving goals will provide direction and clarity of the objectives to be achieved.

b. When all elements or parts of the organization know the goals of the organization clearly and correctly, they will work in the same direction as agreed upon in the planning.

c. With the planning, the organization is able to identify the various obstacles and opportunities that exist in the environment outside the organization, so that they remain in the lane towards the original goal.

d. Helps more efficient and effective planning so that goals are realized.

e. Planning means supervision activities so that it becomes control of the implementation of activities according to procedures.

f. Helps to reduce risk and uncertainty, so that uncertainty can be minimized.

The above opinion is similar to that presented by Siswanto (in Agus Wiranto 2014: 5) which details some of the planning functions as follows:

a. Helping management to adjust to environmental changes.

b. Allows managers to understand the overall picture of operations more clearly.

c. Assist the placement of responsibilities more precisely.

d. Provide a way of giving orders to operate.

e. Facilitate coordination between various parts of the organization.

f. Make goals more specific, detailed and easier to understand.

g. Save time, effort and funds.

Based on the results of interviews and the results of the average recapitulation of the context evaluation questionnaire for each program that has been presented by the researcher, it can be concluded that the context of the Koramil Model in Kodim 1207
/ Pontianak BS is not suitable to be used as a Koramil Model. It is because it is not yet in accordance with the understanding of the reference model which can be used as the best example and represents an object that is useful for assessing a particular system. In the big Indonesian dictionary, it is also stated that the model means the pattern (variety, reference, etc.) of a thing that is intended to be created or produced (Simamarta in Hatya: 2014: 1). Others and as a means used to prepare and improve the ability of new members who will serve in Satkowil before the members are assigned to the community.

The program planning for the Koramil Model only reached fewer criteria. It is because in the preparation of the work program and budget of the Kodim 1207/BS does not plan an activity program for the Koramil Model. Supposedly with the appointment of the Koramil Model, the Koramil Model program is still planned and programmed in the Kodim 1207/BS Budget and work program.

The policy of recruiting personnel to be placed at the Koramil Model must be thoroughly selected in the field of knowledge and skills. With the policy of recruiting personnel who master the field of knowledge and the field of skills, it will be easier to plan for each Koramil Model activity in accordance with a predetermined program and also increase the job satisfaction of personnel in the field.

A good personnel recruitment policy will have a significant effect on the performance and job satisfaction of personnel in the field. $i$ is consistent with the results of Herry Noorwanto's (2014: 261) Dissertation research which states that:

"There is a significant influence of organizational policy on the job satisfaction of Kemhan employees. It means that a quality organizational policy characterized by factual, complementary, coordinated, definite, flexible, and stable information, as well as broad-range will have a significant impact on improving employee job satisfaction ".

2. Entering the Koramil Model Program at Kodim 1207/BS Pontianak

Input evaluation includes: (1) Inputting the Personnel Component Program, (2) Inputting the Material Component Program, (3) Entering the Training Component Program, (4) Input of the Base Component Program, (5) Input of the Software Component Program, (6) Enter the Komsos Program, (7) Enter the TNI Service Program, and (8) Enter the Wanwil Program.

The results of the interview with Major Inf Teguh Rahman as the Commander of the Koramil Model in the Kodim 1207/BS Pontianak and observation, for the aspect of evaluation of input of the Model Koramil Program in Kodim 1207/BS Pontianakhanya reached 37.5 with very few criteria. Of the eight (8) inputs that must be made for the 
requirements to become Koramil Model only three (3) only input the Koramil Model program in the existing Pontianak Kodim 1207/BS, namely (1) Enter the Training Component Program, (2) Enter the Komsos Program, and (3) Enter the TNI Service Program. While five (5) other inputs that do not yet exist are (1) Input Personnel Component Program, (2) Input Material Component Program, (3) Input of Base Component Program, (4) Input Software Component Programs, and (5) Program Input Wanmil.

Data from the average recapitulation of questionnaires distributed to Babainsa personnel only reaches 2.28 and is in quite appropriate criteria, with the details of the Component of Recruitment of Personnel is 2.7 (Appropriate), Material Component as needed is 1.4 (Less Compliant), Component of Exercise activity is 2.8 (Corresponding), Component of Base of Base is 1.5 (Inadequate), Software Component as needed is 1.2 (Less In Accordance), Komsos Program Activity is 2.8 (Appropriate), Activity The Bakti TNI Program is 3.1 (Appropriate), and the Wanwil Program Activity is 2.8 (Appropriate).

The results of the interview data and questionnaire were strengthened by the results of the interview to Mayor Inf Baisumi as the Operational Section Officer on 11 August 2018 stating that all program inputs at the Koramil Model at the Kodim 1207/BS Pontianak were not yet implemented, this was due to lack of good planning made, so that it can be used as a guideline for input at the Koramil Model in Kodim 1207/BS Pontianak.

The results of the interviews and the results of the recapitulation of the average input evaluation questionnaire for each program that was presented by the researcher found that the input of the Koramil 1207-02/PS had not met the requirements as a Koramil Model. Thus it can be concluded that in context Koramil 1207-02/PS Kodim 1207/BS has not been able to be used as a Koramil Model.

The results of the Koramil Model Program input data in the Kodim 1207/BS Pontianak have not been in accordance with the input, because the input is very dependent on the context (planning) of the Koramil Model program in the Pontianak 1207/BS Kodim that has been made. It is because the input (input) in this study is the selection of planning that has been made about the components needed or needed in the program. It is as stated by Siswanto (in Agus Wiranto 2014: 9) as follows:

"Input (input) is a form of activity evaluating or selecting planning from everything that becomes a form of the need for organizations, business materials and so on. Input activities become an objective form of evaluations carried out, whether in the form of products, government and so on.

Based on the theory put forward by Siswanto, it can be concluded that the input (input) of the Koramil Model program in Kodim 1207/BS Pontianak is included in the criteria lacking due to the context (planning) of the Koramil Model program in Kodim 1207/BS Pontianak which will be selected still lacking or incomplete .

Input (input) Koramil Model program at Kodim 1207/BS Pontianak has not received maximum results as expected, it is expected that Danramil 1207-02/PS to be able to give guidance and direction to Koramil Model personnel in Kodim 1207/BS Pontianak in completing every planning needed in the input (input) the Koramil Model program at Kodim 1207/BS Pontianak. It is because with good leadership, one of which is indicated by the provision of guidance and direction, it will affect the work satisfaction of personnel, and if the personnel feel satisfaction, then the personnel will work well and produce good work results as well.

Good leadership towards personnel will have a significant effect on the job satisfaction of personnel in the field. It is consistent with the results of Herry Noorwanto's (2014: 261) Dissertation research which states that:

"There is a significant influence of leadership on the job satisfaction of Kemhan employees. It gives meaning that effective leadership characterized by the ability of leaders regarding selfdirection, flexibility, teamwork, strategy, decision making, managing change, delegation, communication, negotiation, power, and influence, will contribute significantly to increased job satisfaction employee ".

3. Process of Implementing the Model Koramil Program at Kodim 1207/BS Pontianak

Evaluation of the Koramil Model program implementation process in Kodim 1207/BS Pontianak consists of: (1) Personnel Component Program Process, (2) Process Material Component Program, (3) Process Component Training Program, (4) Base Component Program Process, (5) Software Component Program Process, (6) Komsos Program Process, (7) TNI Service Program Process and (8) Wanwil Program Process.

Process evaluation in this study is used to detect or predict the procedure design or implementation plan during the implementation phase, providing information for program decisions and as a recording or archive of procedures that have occurred about the process of implementing the Koramil Model program at Kodim 1207/BS Pontianak.

The evaluation of the process in this study is in accordance with the opinion of Endang Mulyatiningsih (in Agus Wiranto 2014: 1) which states that:

"Process evaluation aims to identify or predict obstacles to the implementation of activities or program implementation. Evaluation is done by recording or 
documenting each incident in the implementation of activities, monitoring activities that have the potential to inhibit and cause unexpected difficulties, find specific information that is outside the plan; assess and explain the actual process. During the evaluation process, evaluators are required to interact with program implementing staff continuously ".

The results of interviews with Major Inf Teguh Rahman as Commander of the Koramil Model in Kodim 1207/BS Pontianak and observation, aspects of the process evaluation program of the Koramil Model in Kodim 1207/BS Pontianak only reached 37.5 with very few criteria. Of the eight (8) results of the process that must be made for the requirements to become Koramil Model only three (3) results of the Koramil Model program process in the existing Kodim 1207/BS Pontianak, namely (1) the results of the Komsos Program Process, (2) the results of the Consecration Program Process TNI and (3) the results of the Wanwil Program Process. Whereas the other five (5) did not yet exist were Input (1) Personnel Component Program Process, (2) Process of Material Component Program, (3) Process of Component Training Program, (4) Process of Base Component Program, and (5) Process of Tool Component Program Soft.

Based on the data from the average recapitulation of questionnaires distributed to Babainsa personnel who only reached 2.3 and included in the criteria sufficiently appropriate, the process of meeting the needs of Material Components was 1.5 (Inadequate), the process of Exercise Component activity was 2.66 (In accordance), The Base Component Strategic Process is 1.7 (Inappropriate), the process of fulfilling the Software Component is 1.5 (Less In Accordance), the Komsos Program Process is 3.0 (Appropriate), the TNI Service Program Process is 3.0 (In Accordance), and the Wanwil Program Activity is 2.8 (Appropriate).

The results of the interview and questionnaire data were strengthened by the results of an interview with Mayor Inf Baisumi as Officer of the Operations Section on August 11, 2018 which stated that the implementation of the program at the Koramil Model at the Kodim 1207/BS Pontianak had not all been carried out, this was due to lack of facilities and infrastructure. by the Koramil Model at Kodim 1207/BS Pontianak.

Based on the results of the interview and the results of the recapitulation of the average questionnaire evaluation of input for each program that has been presented by the researcher, it can be concluded that the Koramil Model Kodim 1207/Pontianak BS process has not been able to be used as a Koramil Model. This is because in the process of implementing the Koramil Model program in Kodim 1207/BS Pontianak many programs are not implemented and only a few programs can be implemented. The process of implementing the program is the core of an implementation of a program that must be carried out in a program, because the implementation process is the implementation of activities or efforts carried out to carry out all plans and policies that have been formulated and determined with all needs or tools. necessary tools. This is as stated by Parlata Westa (in Agus Wiranto 2014: 2) as follows:

"Implementation or implementation of programs are activities or efforts carried out to carry out all program and policy plans that have been formulated and determined with all the necessary needs or tools, who carries out, where to implement it, when to implement it, when ending and how to do it ".

The same thing was stated by Syukur Abdullah (in Agus Wiranto 2014: 2) as follows:

"Implementation is a process of a series of follow-up activities after a plan and policy are established which consists of decision making. Startegs and operational steps taken to realize a program or policy become a reality in order to achieve the targets and programs that were originally set."

It is expected that the Commander of the Koramil Model at the Kodim 1207/BS Pontianak should immediately find a solution or other alternative to be able to solve this problem. This must be immediately broken down because implementation is the core of a program that has been made. One alternative that is to overcome this is to divide the tasks into each personnel according to the characteristics of the work that the personnel are capable and workable. Personnel who are given appropriate assignments with the characteristics of their work will get satisfaction in their work, so that the implementation of the Koramil Model program at Kodim 1207/BS Pontianak can be implemented well and the entire program can be carried out.

Job characteristics will have a significant effect on the job satisfaction of personnel in the field. This is consistent with the results of Herry Noorwanto's (2014: 261) Dissertation research which states that:

"There is a significant influence on job characteristics on job satisfaction of Kemhan employees. This means that work that fulfills the characteristics of skill variation, task identity, task significance, autonomy, and feedback, will have a significant influence on improving employee job satisfaction."

4. Results of the Koramil Model Program at Kodim 1207/BS Pontianak

Evaluation of results (products) on the implementation of the Koramil Model program at 
Kodim 1207/BS Pontianak attempts to assess the impact, constraints, and decision-making of the implementation of the Koramil Model program in the Kodim 1207/BS Pontianak which will be carried out by comparing findings or facts contained in the components evaluation with predetermined standards or criteria.

Evaluation of the results of the implementation of the Koramil Model program in Kodim 1207/BS Pontianak consists of (1) Results of the Personnel Component Program, (2) Results of the Material Component Program, (3) Results of the Component Training Program, (4) Results of the Base Component Program, (5) Results Software Component Program, (6) Komsos Program Results, (7) TNI Service Program Results, and (8) Wanwil Program Results.

In connection with the implementation of the Koramil Model program in the Kodim 1207/BS Pontianak which had been running long enough from 2014, the implementation of the program could have a good impact and could be used as a model Koramil for other Koramil, especially from the completeness of facilities and infrastructure as well as the achievements of Koramil Model personnel at Kodim 1207/BS Pontianak.

Interviews with Major Inf Teguh Rahman as Commander of the Koramil Model in the Kodim 1207/BS Pontianak and observations, the evaluation aspects of the results of the Koramil Model Program at Kodim 1207/BS Pontianak only scored 50 with fewer criteria. While of the eight (8) results that must be made for the requirements to become Koramil a new model four (4) results of the Koramil Model program in the existing Kodim 1207/BS Pontianak, namely (1) Results of the Training Component Program, (2) Results of the Software Component Program , (3) Komsos Program Results, and (4) Results of the TNI Service Program. Whereas for the other four (4) non-existent results including (1) Results of the Personnel Component Program, (2) Results of the Material Component Program, (3) Results of the Base Component Program, and (4) Results of the Wanwil Program.

Data from the average recapitulation of questionnaires distributed to Babinsa personnel who only reached 2.2 with sufficient categories is appropriate, with details of the fulfillment of the Material Component is 1.66 (Fairly Appropriate), the results of the Exercise Component implementation are 2.3 (Fairly Appropriate), The results of the Base Component strategic selection are 1.3 (Inadequate), the results of meeting the requirements of the Software Component are 1.3 (Less In Accordance), the results of the Komsos Program implementation are 2.8 (In Accordance), the Results of the TNI Service Program Implementation are 3, 1 (In Accordance), and the Implementation Results of the Wanwil Program are 3.1 (Appropriate).
The results of the interview data and questionnaire were strengthened by the results of the interview with Mayor Inf Baisumi as the Operational Section Officer on 11 August 2018 which stated that the program input at the Koramil Model at Kodim 1207/BS Pontianak showed poor results. With this result, it should be for the Dandim to immediately decide on the implementation of the program at the Koramil Model at Kodim 1207/BS Pontianak, this is because the program cannot be implemented as expected.

Based on the results of interviews and the results of the recapitulation of the average results evaluation questionnaire for each program that has been presented by the researcher, it can be concluded that the results of the implementation of the 120702/PS Koramil program are not yet suitable to be used as the Koramil Model.

In relation to the evaluation data on the Koramil Model program at Kodim 1207/BS Pontianak, the Koramil Model in Kodim 1207/BS Pontianakagar should make some efforts and efforts to be used as input in order to solve the problems faced during the implementation of the Koramil Model program in Kodim 1207/BS Pontianak or take a decision to stop the implementation of the Koramil Model program at the Koramil 1207-02/PS Pontianak due to the failure to implement the Koramil Model program as expected.

The decision that must be taken by the Dandim 1207/BS in accordance with the opinion of Arikunto (2010: 22) states that "program evaluation activities are intended to make decisions or follow up on programs that have been implemented." In addition, Suharsimi Arikunto and Cepi Safruddin Abdul Jabar (2009: 22), stated that there were four possible policies that were carried out based on the results in the implementation of a decision program, namely:

a. Stop the program, because it is seen that the program has no benefit, or it cannot be implemented as expected.

b. Revise the program, because there are parts that are not in line with expectations (there are errors but only a few).

c. Continuing the program, because the implementation of the program shows that everything has gone according to expectations and has useful results.

d. Disseminating the program (implementing programs in other places or repeating the program at a later time), because the program works well, it is very good if it is implemented again at another time and place.

In line with the opinion of Suharsimi Arikunto and Cepi Safruddin Abdul Jabar, Farida Yusuf Tayibnapis (2000: 14) argued that the purpose of product evaluation is an assessment carried out in order to see the achievement/success of a program in 
achieving a predetermined goal, which at this stage of evaluation is an evaluator can determine or provide recommendations to evaluators whether a program can be continued, developed/modified, or even stopped.

\section{CONCLUSIONS AND SUGGESTIONS}

\section{A. Conclusions}

The details about the conclusion of the Koramil Model program evaluation at Pontianak's Kodim 1207/BS are as follows:

1. The results of the context evaluation of the Koramil Model program at Kodim 1207/BS Pontianak which contained program planning categorized as poor.

2. The results of the input evaluation of the Model Koramil Program in Kodim 1207/BS Pontianak categorized as very poor.

3. The results of the evaluation of the Koramil Model program implementation process at Kodim 1207/BS Pontianak categorized as poor.

4. The results of the product evaluation (results) of the Koramil Model program at Kodim 1207/BS Pontianak categorized as poor.

B. Suggestions

Based on these conclusions, researchers try to provide recommendations, namely:

1. It is expected for Danramil 1207-02/PS to complete every program planning that will be implemented.

2. It is expected that the Danramil Koramil Model at Kodim 1207/BS Pontianak should look for solutions in the implementation of input.

3. Evaluation of the implementation of the Koramil Model program at Kodim 1207/Pontianak Pontianak, many of which were not implemented.

4. It is hoped that the Dandim 1207/BS Pontianak will make several efforts/efforts to solve the problems that have been faced.

\section{REFERENCE}

Agus Wiranto. 2014. Asas-Asas Manajemen "Pentingnya Perencanaan Sebagai Salah Satu Fungsi Manajemen" Ilmu Pemerintahan Fisip. Universitas Riau.

Farida Yusuf Tayibnapis. 2015. Evaluasi Program dan Instrumen Evaluasi. Jakarta: PT RENIKA CIPTA.

Hatya.com/3284/pengertian-model-menurut-paraahli. Diakses tanggal 25 Juli 2018 pada pukul 21.43 WIB.

Herry Noorwanto. 2014. Pengaruh Kebijakan Organisasi, Kepemimpinan dan Karakteristik Pekerjaan Terhadap Kepuasan Kinerja Serta Implikasinya pada Komitmen Organisasional (Studi Pada
Pegawai Negeri Sipil di Kementrian Pertahanan RI). Disertasi. Program Doktor Ilmu Administrasi Minat Administrasi Publik. Fakultas Ilmu Administrasi Universitas Brawijawa Malang.

Staf Umum Teritorial Angkatan Darat Tahun 2014, Buku Pedoman Koramil Model.

Suharsimi Arikunto dan Cepi Safrudin Abdul Jabar. 2009. Evaluasi Program Pendidikan. Jakarta: Bumi Aksara.

Suharsimi Arikunto. 2010. Prosedur Penelitian, Suatu Pendekatan Praktik. Jakarta: Rineka Cipta.

UniversitasTanjungpura. Buku Pedoman Penulisan Tesis. Program Pascasarjana Teknologi Pendidikan FKIP- UntanPontinak.

Zainal Arifin. 2016. Evaluasi Pembelajaran. Bandung: PT. Remaja Rosdakarya. 